\title{
MANUFACTURE OF FERMENTED NUTRACEUTICAL MILK PRODUCTS HIGHLY IN SOLUBLE DIETARY FIBER
}
Sobhy,
H. M. ${ }^{1}$; Samia,
M. El-Dieb'
E. A. Emara ${ }^{3}$;

M. A. El-Nawawy ${ }^{4}$ and Safaa A. M. El-Aidie ${ }^{5}$.

${ }^{1}$ Natural Resource Department, Institute of African Research and Studies, Cairo University

${ }^{2}$ Dairy science \& Technology Department, Faculty of Agriculture, Cairo University.

${ }^{3,5}$.Dairy science\& Technology Department, Animal Production Research Institute, Agriculture Research Center, Dokki Giza, Egypt.

4 Food Science Department, Faculty of Agriculture, Ain Shams University, Cairo, Egypt

\begin{abstract}
This study was undertaken to evaluate the feasibility of using soluble dietary fiber and probiotic bacteria to produce nutraceutical fermented cow milk. Fresh cow milk without addition served as a control (T1). $\beta$ - glucan (T2) or glucomannan (T3) was added to fresh cow milk $(30 \mathrm{mg} / \mathrm{L})$. All treatments were heated at $85^{\circ} \mathrm{C} / 10 \mathrm{~min}$, cooled to $45^{\circ} \mathrm{C}$. Each treatment inoculated with yoghurt starter culture (Yo) or $L b$. acidophilus $(A)$ or $L b$. helveticus $(H)$ at a level of $3 \%$ and incubated at $42^{\circ} \mathrm{C}$. After fermentation all samples were cooled and keep at $4^{\circ} \mathrm{C}$ for 1 day, yoghurt mixed with fermented milk contains $L b$. acidophilus or/ and $L b$. helveticus as well as $L b$. acidophilus fermented milk mixed with $L b$. helveticus at ratio $1: 1$ and 1:1:1. Titratable acidity, microbiological analysis and sensory evaluation were determined in all samples. Incubation time was different among all treatments to reach the titratable acidity $0.7 \%$, where it was lower in control than other treatments. Titratable acidity of fermented milk was affected by adding soluble dietary fiber, where fermented milk with $\beta$ - glucan (T2) or glucomannan (T3) had lower acidity than fermented milk without dietary fiber (T1). Types of starter cultures had no significant effect on the titratable acidity of fermented milk. Addition of $\beta$-glucan or glucomannan decreased total lactic acid bacterial counts (TLAB) as compared with control. Treatments of $\mathrm{Yo}, \mathrm{A}$ and $H$ resulted in significant lower TLAB count than mixed treatments. Spore forming counts in T2 and T3 treatments were significantly lower than control. Addition of $\beta$ glucan or glucomannan improved the body and texture, compared to the control, particularly, $\mathrm{Yo}+\mathrm{H}$ and $\mathrm{Yo}+\mathrm{A}+\mathrm{H}$.
\end{abstract}

Keywords: soluble dietary fiber; starter cultures; $\beta$-glucans; Glucomannan

\section{INTRODUCTION}

Fermented milk products containing probiotic bacteria are some of the most popular fermented food products in the world. It has numerous health benefits due to the functional properties of their viable microorganisms and a health claim for fermented milk which allowed towards improved lactose digestion for individuals with lactose maldigestion (EFSA, 2010). Probiotics have been defined as "Live microorganisms which when administered in adequate amounts confer a health benefit to the host" by improving their intestinal microbial balance. Probiotic bacteria have been shown to provide several therapeutic benefits such as modification of the 
Sobhy, H. M. et al.

immune system, alleviation from lactose intolerance, maintained remission of Crohn's disease, faster relief from diarrhea, and prevention of urogenital infections (Reid, 1999; Reid et al., 2003 a,b), decrease in levels of blood lipids, nutrients synthesis and their bioavailability enhancement and prevention of cancer and mutation activities in the human gut (Noh et al., 1997; Gorbach, 2000; Kailasapathy and Chin, 2000; Cremonini et al., 2001; Kopp-Hoolihan, 2001; Femia et al., 2002; Rafter, 2002 and Kim et al., 2008). Soluble dietary fibers are present in small quantities in almost each and every commodity and in combination with insoluble dietary fiber contribute towards total dietary fiber. The beneficial properties of soluble dietary fibers have been associated with their significant role in human physiological function. It includes, reductions in cholesterol level and blood pressure, prevention of gastrointestinal problems, protection against onset of several cancers, which include colorectal, prostate, and breast cancer, increased mineral bioavailability, and many more are the salient features of their potential (Chawla and Patil 2010).

As active compounds of the soluble dietary fiber, $\beta$-glucans are naturally-occurring polysaccharides found in the cell walls of yeast, fungi, bacteria and cereal plants such as oat, barley (Akramiene et al. 2007, Chen and Seviour, 2007). $\beta$-Glucans are a diverse class of long-chain glucose polymers that have a backbone of $\beta$-(1-3)-linked $\beta$-D glucopyranosyl units with primarily $\beta-(1,4)$ - or $(1,6)$ - linked side chains. These naturally occurring substances have been shown to provide health benefits including enhancing the bio-defense activity against bacterial, viral, fungal and parasitic challenge, increasing hematopoiesis and radioprotection, stimulating the wound healing response, stimulating the immune mechanisms of the host and have also antimicrobial effects, decreasing blood lipid concentration, reduce the risk of coronary and ischemic heart diseases, protection against infection, inhibition of tumor development, and promotion of tumor regression (Delatte et al. 2001; Hong et al. 2004; Maki et al. 2007; Yoon et al. 2008; Driscoll et al. 2009; Shah et al. 2009 and Asano et al. 2012). S. cerevisiae $\beta$-glucan showed protective effects against genotoxicity and cytotoxicity of some drugs, such as cyclophosphamide, adriamycin and cisplatin. Such effects have been attributed to the ability of $\beta$-glucan to trap free radicals produced in the course of biotransformation of these drugs (Tohamy et al., 2003). In addition, it has been demonstrated that $\beta$-glucan-containing products are potent antioxidants, preventing damage caused by $\mathrm{H}_{2} \mathrm{O}_{2}$ and other reactive oxygen species (Laugier et al. 2012).

Mannan polysaccharides are widespread in nature. They are considered to be one of the major components of hemicellulose in the cell walls of plants (Moreira and Filho, 2008). Microbes are a rich source of mannans, so it called 'mannan oligosaccharides' which are derived from the outer layer of the yeast cell walls especially from Saccharomyces cerevisiae. Mannans represent carbohydrates, especially polysaccharides, that contain mannose (sugar) residues. They can be divided into four types; mannan, galactomannan, glucomannan and galactoglucomannan (Tester and Al-Gazzewi, 2013). Mannan oligosaccharides are often promoted as an alternative to antibiotics 
in the animal feed industry, where mannose may prevent attachment of the intestinal pathogens such as Salmonella species and Escherichia coli to the gut mucosa (Benites et al. 2008). Also mannan oligosaccharides from yeast cells had a significant impact with respect to change the bacterial ecology in the gut by stimulating the immune system (Miguel et al. 2004; Bozkurt et al. 2009; Corrigan et al. 2011)).

The objective of this study is to measure and compare the sensory and microbiological characteristics of fermented nutraceutical milk products containing $\beta$-glucans and glucomannan.

\section{MATERIALS AND METHODS}

Fresh raw cows milk was obtained from the herd of the Faculty of Agriculture, Cairo University. Giza,Egypt. Yoghurt cultures YC-fast1(Str.thermophilus, Lb.bulgaricus), Lactobacillus acidophilus La -5 and Lactobacillus helveticus Lh. BO2 were obtained from Chr. Hansens Laboratories, Copenhagen Denmark. Violet red bile glucose agar, oxytetracycline - glucose -yeast extract agar (OGYE Agar), plate count agar (tryptone glucose yeast agar) medium were obtained from Oxoid Ltd., Basingstoke, Hampshire, England. $\beta$-glucan and glucomannan were obtained from Alltech Company, USA.

Fresh cow milk (18 $\mathrm{kg}, 3 \%$ fat) was divided into three equal parts. The first part of milk served as a control, while the $\beta$-glucan $(30 \mathrm{mg} / \mathrm{L})$ was added to the second part and glucomannan $(30 \mathrm{mg} / \mathrm{L})$ was added to the third part of milk. All parts were heated at $85^{\circ} \mathrm{C}$ for $10 \mathrm{~min}$, cooled to $45^{\circ} \mathrm{C}$. Each part of milk was subdivided into three equal portions, the first portion inoculated with the yoghurt starter culture. The second portion inoculated with the $L$. acidophilus. The third portion was inoculated with the L. helveticus. The inoculation rate was $3 \%(\mathrm{w} / \mathrm{w})$ for all cultures. The inoculated milk was transferred into polystyrene plastic cups and incubated at $42^{\circ} \mathrm{C}$. Once fermentation was completed (acidity reached $0.7 \%$ ) all samples were cooled and kept at $4^{\circ} \mathrm{C}$ until the second day. Yoghurt was mixed with fermented milk containing $L b$. acidophilus or/ and Lb. helveticus at ratio 1:10r 1:1:1. Also fermented milk containing $L b$. acidophilus mixed with $L b$. helveticus at the ratio of 1:1 (Fig. 1). Titratable acidity, microbiological analysis and sensory evaluation were determined in all samples when fresh.

Titratable acidity, fat, total protein (T.P), ash and total solids (T.S) of fermented milk samples were determined according to AOAC (2012).

Fermented milk samples were kept in the refrigerator approximately 1 day before the microbiological analysis. Total lactic acid bacterial count (TLAB) were estimated using MRS agar medium as recommended by the American Public Health Association (APHA, 2004), plates were incubated at $37^{\circ} \mathrm{C}$ for $48 \mathrm{hr}$. The count of aerobic spore forming bacteria was carried out as described by Luck, 1981, plates were incubated at $32^{\circ} \mathrm{C}$ for $48 \mathrm{hr}$. Coliform counts were enumerated using violet red bile glucose agar medium, as reported by APHA, 2004, plates were incubated at $37^{\circ} \mathrm{C}$ for $24 \mathrm{hr}$. Moulds and yeasts were enumerated using oxytetracycline-glucose-yeast extract agar (OGYE Agar) medium according to IDF, 1990 , plates were incubated at $25^{\circ} \mathrm{C}$ for 5 days. 


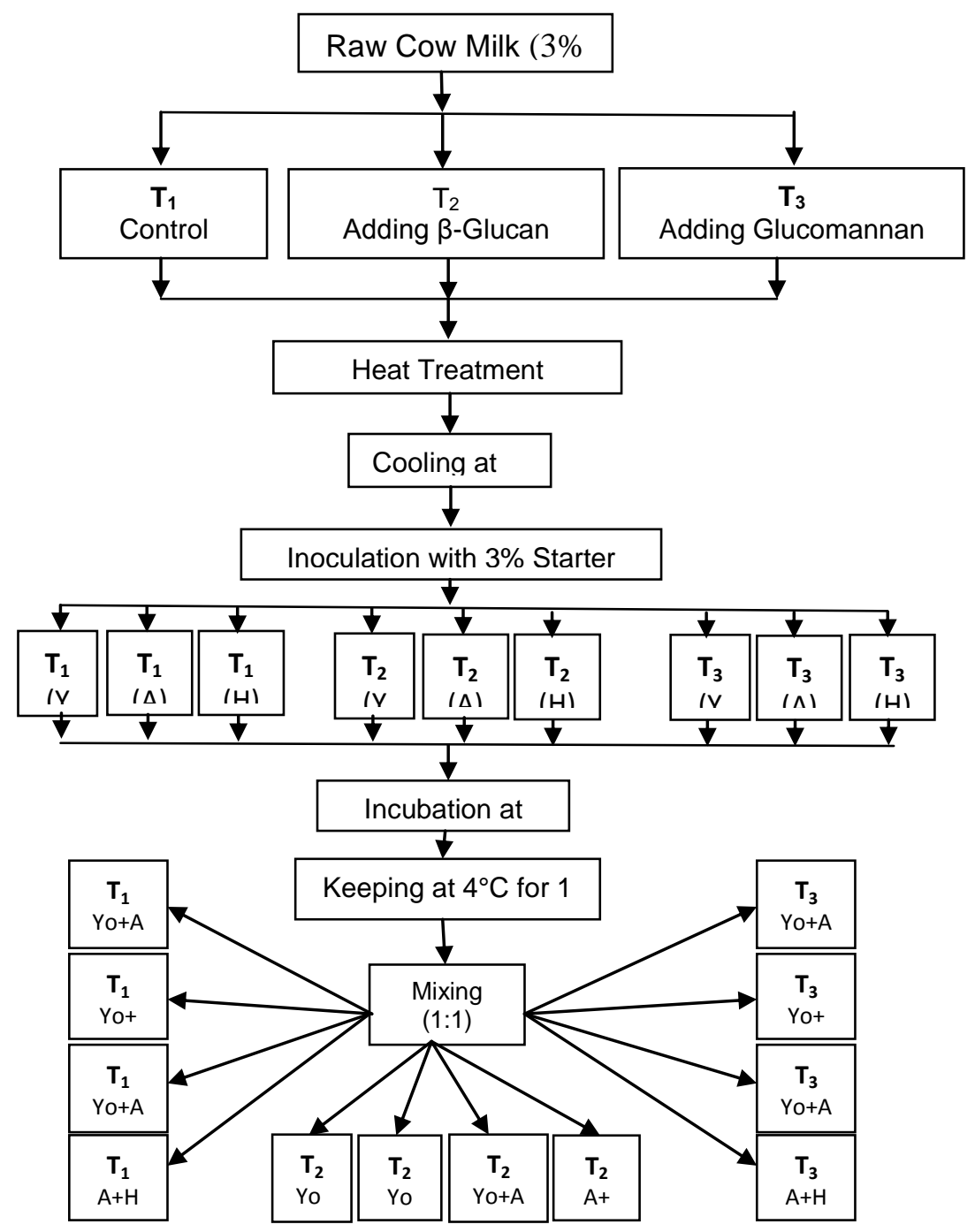

Fig(1):Schematic representation of the process used in making the fermented nutraceutical milk products

The fermented milk samples were judged by the staff members of the Dairy Science Department, Faculty of Agriculture, Cairo University and Dairy Science \&Technology Department, Animal Production Research Institute, Agriculture Research Center, Ministry of Agriculture. The fermented milk samples were organoleptically scored for Flavor (45 points), body and texture (30 points), acidity (10 points) and appearance (15 points) with a total acceptance of 100 points, as mentioned by El-Senaity (1999).

The experiments were repeated in triplicates and each analysis duplicates, and the average results were recorded. All statistical analysis was 
carried out using SPSS- 21. Overall effects of treatments were analyzed conducting a 2-ways ANOVA; statistically different groups were determined by Duncon test $(P \leq 0.05)$.

\section{RESULTS AND DISCUSSION}

Chemical composition of all fermented milk samples was almost the same, where it contained $3.67 \%$ fat, $3.58 \%$ total protein, $0.77 \%$ ash and $12.50 \%$ total solids.

As can be observed from the results in Table (1) and Fig. (2), the incubation time needed to reach the titratable acidity of $0.7 \%$ was different among all treatments. The times were $3 \mathrm{hr}, 8 \mathrm{hr}$ and $5 \mathrm{hr}$ for yoghurt starter culture (Yo), Lb. acidophilus $(\mathrm{A})$ and $L b$. helveticus $(\mathrm{H})$ in control treatment (T1), respectively. While the times were $4 \mathrm{hr}, 18 \mathrm{hr}$ and $6 \mathrm{hr}$ for $\mathrm{Yo}, \mathrm{A}$ and $\mathrm{H}$ in $\beta$-glucan treatment (T2). The same results were obtained for glucomannan treatment (T3). These results might be due to $\beta$-glucan or glucomannan are considered as antibacterial agents (EI-Dieb et al. 2014). After fermentation in all samples were kept at $4^{\circ} \mathrm{C}$ for 1 day then the treatments of $\mathrm{Yo}+\mathrm{A}, \mathrm{Yo}+\mathrm{H}$, $\mathrm{Yo}+\mathrm{A}+\mathrm{H}$ and $\mathrm{A}+\mathrm{H}$ were prepared by mixing as shown in Fig (1). This technique was followed to avoid the competition of different starter cultures used. As can be observed from the results in Table (1) or Fig (2), titratable acidity of fermented milk was affected by adding soluble dietary fiber, where fermented milk with $\beta$-glucan (T2) or glucomannan (T3) had lower acidity than fermented milk without dietary fiber (T1). The same data in Table (1) or Fig. (2), showed that the starter cultures type had no significant effect on the development of the titratable acidity of fermented milk after 1 day of storage at $4^{\circ} \mathrm{C}$.

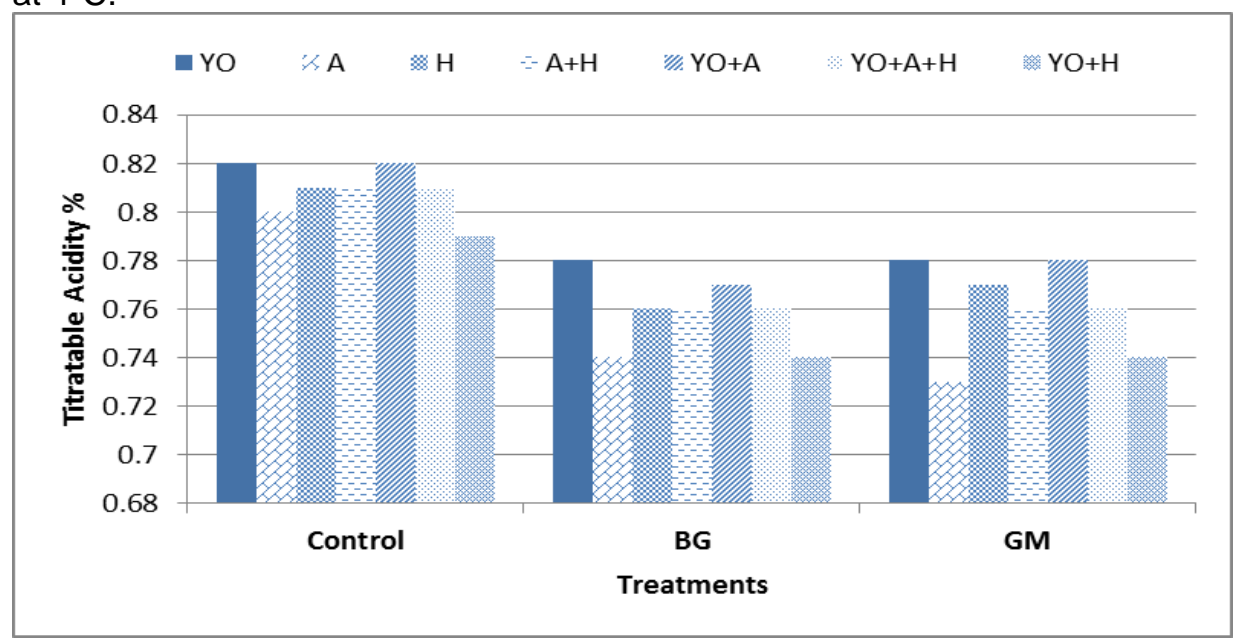

Fig. (2):Titratable acidity of fermented nutraceutical milk products made with soluble dietary fiber after 1 day keeping at $4^{\circ} \mathrm{C}$. 
Sobhy, H. M. et al.

The different capital letters have a significant effect between treatments at the level 0.05 and the different small letters have a significant effect for starter culture at the level 0.05 .

Table(1):Incubation time and titratable acidity of fermented nutraceutical milk products made with soluble dietary fiber.

\begin{tabular}{|c|c|c|c|}
\hline Treatments & Starter culture & Incubation time & ${ }^{\star}$ Acidity \% \\
\hline \multirow{7}{*}{$\begin{array}{l}(\mathrm{T} 1) \\
\text { Control }\end{array}$} & Yo & 3 & $0.820^{\mathrm{Aa}}$ \\
\hline & $A$ & 8 & $0.800^{\text {Aa }}$ \\
\hline & $\mathrm{H}$ & 5 & $0.810^{\mathrm{Aa}}$ \\
\hline & ${ }^{* \star} \mathrm{Yo}_{\mathrm{O}} \mathrm{A}$ & - & $0.810^{\text {Aa }}$ \\
\hline & ${ }^{* *} \mathrm{Yo}+\mathrm{H}$ & - & $0.820^{\mathrm{Aa}}$ \\
\hline & ${ }^{* *} \mathrm{Yo}+\mathrm{A}+\mathrm{H}$ & - & $0.810^{\text {Aa }}$ \\
\hline & ${ }^{* *} \mathrm{~A}+\mathrm{H}$ & - & $0.790^{\text {Aa }}$ \\
\hline \multirow{7}{*}{$\begin{array}{l}\text { (T 2) } \\
\text { With adding } \beta \text {-glucan }\end{array}$} & Yo & 4 & $0.780^{\mathrm{Ba}}$ \\
\hline & $A$ & 18 & $0.740^{\mathrm{Ba}}$ \\
\hline & $\mathrm{H}$ & 6 & $0.760^{\mathrm{Ba}}$ \\
\hline & ${ }^{* *} \mathrm{Yo}+\mathrm{A}$ & - & $0.760^{\mathrm{Ba}}$ \\
\hline & ${ }^{* *} \mathrm{Yo}+\mathrm{H}$ & - & $0.770^{\mathrm{Ba}}$ \\
\hline & ${ }^{* *} \mathrm{Yo}+\mathrm{A}+\mathrm{H}$ & - & $0.760^{\mathrm{Ba}}$ \\
\hline & ${ }^{\star *} \mathrm{~A}+\mathrm{H}$ & - & $0.740^{\mathrm{Ba}}$ \\
\hline \multirow{7}{*}{$\begin{array}{l}\text { ( ( 3 3) } \\
\text { With adding glucomannan }\end{array}$} & Yo & 4 & $0.780^{\mathrm{Ba}}$ \\
\hline & $A$ & 18 & $0.730^{\mathrm{Ba}}$ \\
\hline & $\mathrm{H}$ & 6 & $0.770^{\mathrm{Ba}}$ \\
\hline & ${ }^{* *} \mathrm{Yo}+\mathrm{A}$ & - & $0.760^{\mathrm{Ba}}$ \\
\hline & ${ }^{* *} \mathrm{Yo}+\mathrm{H}$ & - & $0.780^{\mathrm{Ba}}$ \\
\hline & ${ }^{* *} \mathrm{Yo}+\mathrm{A}+\mathrm{H}$ & - & $0.760^{\mathrm{Ba}}$ \\
\hline & ${ }^{* \star} \mathrm{A}+\mathrm{H}$ & - & $0.740^{\mathrm{Ba}}$ \\
\hline
\end{tabular}

Yo: Yoghurt starter cultures, A: Lb. acidophilus $\mathrm{H}$ : Lb. helveticus

${ }^{\star}$ Acidity was determined after 1 day kept at $4^{\circ} \mathrm{C}$.

${ }^{\star \star}$ these treatments were prepared by mixing treatment Yo, $\mathrm{A}$ or $\mathrm{H}$ after fermentation.

The microbiological analysis were performed after fermentation and keeping at $4^{\circ} \mathrm{C}$ for 1 day. Mould and yeast were not detected in all treatments (data not mentioned). This might be attributed to follow very good hygienic condition during experimental manufacture and handling. As shown in Table (2), a significant difference $(P<0.05)$ was observed for total lactic acid bacterial counts (TLAB) between all treatments. The addition of $\beta$ glucan or glucomannan decreased the TLAB counts, as compared with control. These results might be due to anti microbiological effect of $\beta$-glucan and glucomannan. Regarding the type of starter cultures, treatments of Yo, A and $\mathrm{H}$ resulted in a significant lower TLAB than other treatments. TLAB ranged from $6.102-7.816 \log _{10} \mathrm{cfu} / \mathrm{ml}$ in all treatments. The obtained results from the same Table (2) showed that spore forming counts were significantly affected by adding dietary fiber. Spore forming counts in treatment T2 and T3 were significantly lower, where it ranged from $0.150-0.849 \log _{10} \mathrm{cfu} / \mathrm{ml}$ than control (T1) ranged from 1.500-1.977 $\log _{10} \mathrm{cfu} / \mathrm{ml}$. 
Table (2): Lactic acid bacteria and spore forming bacterial counts (Log ${ }_{10} \mathrm{cfu} / \mathrm{ml}$ ) of fermented nutraceutical milk products made with soluble dietary fiber.

\begin{tabular}{|l|c|c|c|}
\hline Treatments & Starter culture & $\begin{array}{c}\text { Total Lactic Acid } \\
\text { Bacteria }\end{array}$ & $\begin{array}{c}\text { Spore forming } \\
\text { Bacterial Count }\end{array}$ \\
\hline \multirow{4}{*}{ (T 1) } & $\mathrm{Yo}$ & $7.166^{\mathrm{Abc}}$ & $1.650^{\mathrm{Aa}}$ \\
\cline { 2 - 4 } & $\mathrm{A}$ & $6.845^{\mathrm{Ac}}$ & $1.977^{\mathrm{Aa}}$ \\
\cline { 2 - 4 } & $\mathrm{H}$ & $6.871^{\mathrm{Ac}}$ & $1.738^{\mathrm{Aa}}$ \\
\cline { 2 - 4 } & $\mathrm{A}+\mathrm{H}$ & $7.397^{\mathrm{Abc}}$ & $1.650^{\mathrm{Aa}}$ \\
\cline { 2 - 4 } & $\mathrm{Yo}+\mathrm{A}$ & $7.418^{\mathrm{Aab}}$ & $1.801^{\mathrm{Aa}}$ \\
\cline { 2 - 4 } & $\mathrm{Yo}+\mathrm{H}$ & $7.626^{\mathrm{Aab}}$ & $1.500^{\mathrm{Aa}}$ \\
\cline { 2 - 4 } (T 2) & $\mathrm{Yo}+\mathrm{A}+\mathrm{H}$ & $7.816^{\mathrm{Aa}}$ & $1.650^{\mathrm{Aa}}$ \\
\cline { 2 - 4 } With adding B-glucan & $\mathrm{Yo}$ & $6.544^{\mathrm{Bbc}}$ & $0.500^{\mathrm{Ba}}$ \\
\cline { 2 - 4 } & $\mathrm{A}$ & $6.127^{\mathrm{Bc}}$ & $0.150^{\mathrm{Ba}}$ \\
\cline { 2 - 4 } & $\mathrm{H}$ & $6.161^{\mathrm{Bc}}$ & $0.588^{\mathrm{Ba}}$ \\
\cline { 2 - 4 } & $\mathrm{A}+\mathrm{H}$ & $6.390^{\mathrm{Bbc}}$ & $0.588^{\mathrm{Ba}}$ \\
\cline { 2 - 4 } & $\mathrm{Yo}+\mathrm{A}$ & $7.323^{\mathrm{Bab}}$ & $0.698^{\mathrm{Ba}}$ \\
\cline { 2 - 4 } & $\mathrm{Yo}+\mathrm{H}$ & $7.544^{\mathrm{Bab}}$ & $0.500^{\mathrm{Ba}}$ \\
\cline { 2 - 4 } & $\mathrm{Yo}+\mathrm{A}+\mathrm{H}$ & $7.698^{\mathrm{Ba}}$ & $0.801^{\mathrm{Ba}}$ \\
\cline { 2 - 4 } (T 3) & $\mathrm{Yo}$ & $6.968^{\mathrm{Bbc}}$ & $0.849^{\mathrm{Ba}}$ \\
\cline { 2 - 4 } With adding glucomannan & $\mathrm{A}$ & $6.102^{\mathrm{Bc}}$ & $0.150^{\mathrm{Ba}}$ \\
\cline { 2 - 4 } & $\mathrm{H}$ & $6.306^{\mathrm{Bc}}$ & $0.650^{\mathrm{Ba}}$ \\
\cline { 2 - 4 } & $\mathrm{A}+\mathrm{H}$ & $6.422^{\mathrm{Bbc}}$ & $0.650^{\mathrm{Ba}}$ \\
\cline { 2 - 4 } & $\mathrm{Yo}+\mathrm{A}$ & $6.836^{\mathrm{Bab}}$ & $0.500^{\mathrm{Ba}}$ \\
\cline { 2 - 4 } & $\mathrm{Yo}+\mathrm{H}$ & $7.067^{\mathrm{Bab}}$ & $0.738^{\mathrm{Ba}}$ \\
\cline { 2 - 4 } & $\mathrm{Yo}+\mathrm{A}+\mathrm{H}$ & $7.457^{\mathrm{Ba}}$ & $0.738^{\mathrm{Ba}}$ \\
\hline
\end{tabular}

Yo: Yoghurt starter, A: Lb. acidophilus, $\quad \mathrm{H}:$ Lb. helveticus

The different capital letters have a significant effect between treatments at the level 0.05 The different small letters have a significant effect for starter culture at the level 0.05 .

The results of sensory evaluation of the different treatments are presented in Table (3). It appears that the addition of $\beta$ - glucan or glucomannan didn't affect significantly flavor scores comparing with the control. On the other hand, the effect of starter cultures kind on flavor was more pronounced. The samples of $\mathrm{Yo}+\mathrm{H}$ was the highest, while the samples of $\mathrm{Yo}+\mathrm{A}, \mathrm{A}$ and $\mathrm{H}$ were the lowest for flavor score. The flavor score for other treatments ranged between $(36.200-38.750)$.

From the results in Table (3), it could be observed that using $\beta$ glucan and glucomannan improved significantly body and texture compared to the control. This might be attributed to the presence of $\beta$ - glucan which is used as thickening, water holding, emulsifying stabilizer or oil- binding agent (Thammakiti et al. 2004). The sample $\mathrm{Yo}+\mathrm{H}$ in all treatments had_the highest score (27), while the sample Yo+A had the lowest_(19) scores for body and texture than the other samples. 
Sobhy, H. M. et al.
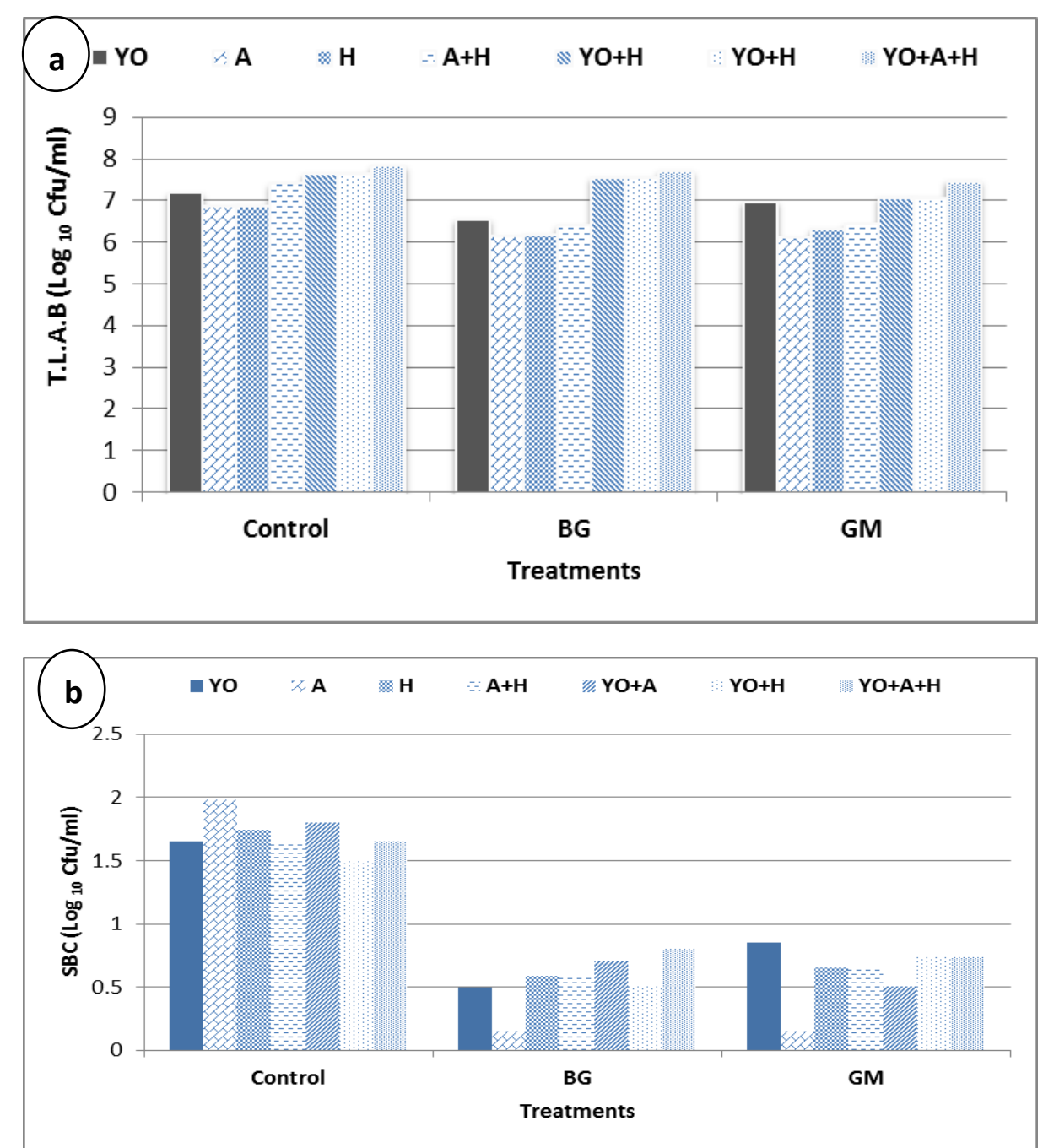

Fig. (3):Lactic acid bacteria (a) and spore forming bacterial counts (b) $\left(\log _{10} \mathrm{cfu} / \mathrm{ml}\right)$ of fermented nutraceutical milk products made with soluble dietary fiber.

All samples had almost similar scores for acidity, which ranged from (7.000 - 8.250). There were no significant differences $(P \leq 0.05)$ in appearance values among treatments and starter cultures. Where all samples had almost similar scores ranging from $12.870-13.800$.

From the results of the same Table (3), treatments $\beta$ - glucan were more superior, followed by control and glucomannan treatments depending on total scores. It related to starter cultures type, $\mathrm{Yo}+\mathrm{H}$ gained the higher total scores than other samples. Fermented milk made using $\beta$ - glucan and culture starter $\mathrm{Yo}+\mathrm{H}$ gained the highest score $(91.000)$, followed by $\mathrm{Yo}+\mathrm{A}+\mathrm{H}$ which gained 88.437. 
Table (3): Sensory evaluation of fermented nutraceutical milk products made with soluble dietary fiber.

\begin{tabular}{|c|c|c|c|c|c|c|}
\hline Treatments & $\begin{array}{l}\text { Starter } \\
\text { culture }\end{array}$ & $\begin{array}{l}\text { Flavour } \\
\text { (45) }\end{array}$ & $\begin{array}{l}\text { Body and } \\
\text { texture } \\
(30)\end{array}$ & $\begin{array}{l}\text { Acidity\% } \\
\text { (10) }\end{array}$ & $\begin{array}{c}\text { Appearance } \\
\text { (15) }\end{array}$ & $\begin{array}{c}\text { Total score } \\
(100)\end{array}$ \\
\hline \multirow{7}{*}{$\left(\begin{array}{l}(\mathrm{T} 1) \\
\text { Control }\end{array}\right.$} & Yo & $37.800^{\mathrm{Abc}}$ & $23.500^{\text {Cab }}$ & $7.400^{\mathrm{AD}}$ & $13.800^{\mathrm{Aa}}$ & $82.500^{\mathrm{BbC}}$ \\
\hline & $A$ & $34.900^{\text {Acd }}$ & $20.400^{\mathrm{Cb}}$ & $7.000^{A C}$ & $13.600^{\mathrm{Aa}}$ & $75.900^{\mathrm{Bcd}}$ \\
\hline & $\mathrm{H}$ & $31.600^{\text {Acd }}$ & $19.900^{\mathrm{Cb}}$ & $7.500^{A D}$ & $13.300^{\mathrm{Aa}}$ & $72.300^{\mathrm{Bd}}$ \\
\hline & $\mathrm{YO}+\mathrm{A}$ & $34.600^{A d}$ & $20.400^{\mathrm{Cc}}$ & $7.100^{A C}$ & $13.000^{\text {Aa }}$ & $75.100^{\mathrm{Be}}$ \\
\hline & $\mathrm{Yo}+\mathrm{H}$ & $40.900^{\mathrm{Aa}}$ & $25.200^{\mathrm{Ca}}$ & $7.400^{\mathrm{Ab}}$ & $13.000^{\mathrm{Aa}}$ & $86.500^{\mathrm{Ba}}$ \\
\hline & $\mathrm{Yo}+\mathrm{A}+\mathrm{H}$ & $38.600^{\text {Aab }}$ & $21.100^{\text {Cab }}$ & $7.700^{\mathrm{Aa}}$ & $13.500^{\mathrm{Aa}}$ & $80.900^{\mathrm{Bab}}$ \\
\hline & $\mathrm{A}+\mathrm{H}$ & $36.200^{\text {Acd }}$ & $22.400^{\mathrm{Cab}}$ & $7.300^{A C}$ & $13.200^{\mathrm{Aa}}$ & $79.100^{\mathrm{Bd}}$ \\
\hline \multirow{7}{*}{ 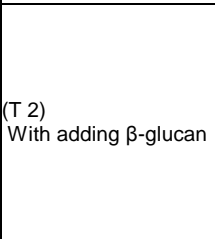 } & Yo & $37.800^{A b c}$ & $26.750^{\text {Aab }}$ & $7.500^{\mathrm{Ab}}$ & $13.625^{\mathrm{Aa}}$ & $85.675^{\mathrm{Abc}}$ \\
\hline & $A$ & $33.875^{\text {Acd }}$ & $24.000^{A b}$ & $7.375^{\mathrm{AC}}$ & $13.125^{\mathrm{Aa}}$ & $77.375^{\text {Acd }}$ \\
\hline & $\mathrm{H}$ & $36.875^{\text {Acd }}$ & $24.875^{A b}$ & $7.000^{A C}$ & $12.870^{\mathrm{Aa}}$ & $81.620^{\mathrm{Ad}}$ \\
\hline & $\mathrm{Yo}+\mathrm{A}$ & $36.500^{\mathrm{Ad}}$ & $24.937^{\mathrm{AC}}$ & $7.812^{\mathrm{Aa}}$ & $13.125^{\mathrm{Aa}}$ & $82.375^{\mathrm{Ae}}$ \\
\hline & $\mathrm{Yo}+\mathrm{H}$ & $41.875^{\mathrm{Aa}}$ & $27.000^{A a}$ & $8.250^{\mathrm{Aa}}$ & $13.875^{\mathrm{Aa}}$ & $91.000^{\mathrm{Aa}}$ \\
\hline & $\mathrm{Yo}+\mathrm{A}+\mathrm{H}$ & $40.125^{\text {Aab }}$ & $27.250^{\text {Aab }}$ & $7.687^{\text {Aab }}$ & $13.375^{\mathrm{Aa}}$ & $88.437^{\text {Aab }}$ \\
\hline & $\mathrm{A}+\mathrm{H}$ & $38.625^{\text {Acd }}$ & $27.000^{\text {Aab }}$ & $7.750^{\text {Aab }}$ & $13.125^{\mathrm{Aa}}$ & $86.500^{\text {Ad }}$ \\
\hline \multirow{7}{*}{$\begin{array}{l}(\mathrm{T} 3) \\
\text { With adding } \\
\text { glucomannan }\end{array}$} & Yo & $37.100^{A b c}$ & $23.100^{\text {Bab }}$ & $7.150^{\mathrm{AC}}$ & $13.600^{\mathrm{Aa}}$ & $80.950^{\mathrm{BbC}}$ \\
\hline & $A$ & $34.600^{\text {Acd }}$ & $26.600^{\mathrm{Bb}}$ & $8.000^{\mathrm{Aa}}$ & $13.100^{\mathrm{Aa}}$ & $82.300^{\mathrm{Bcd}}$ \\
\hline & $\mathrm{H}$ & $32.200^{\text {Acd }}$ & $26.2000^{\mathrm{Bb}}$ & $7.800^{\mathrm{Aa}}$ & $13.000^{A a}$ & $79.200^{\mathrm{Bd}}$ \\
\hline & $\mathrm{YO}+\mathrm{A}$ & $33.875^{\mathrm{Ad}}$ & $19.0000^{\mathrm{BC}}$ & $7.600^{\text {Aab }}$ & $13.100^{\mathrm{Aa}}$ & $73.575^{\mathrm{Be}}$ \\
\hline & $\mathrm{YO}+\mathrm{H}$ & $39.300^{\mathrm{Aa}}$ & $25.7000^{\mathrm{Ba}}$ & $8.1500^{\mathrm{Aa}}$ & $13.600^{\mathrm{Aa}}$ & $86.750^{\mathrm{Ba}}$ \\
\hline & $\mathrm{Yo}+\mathrm{A}+\mathrm{H}$ & $38.750^{\text {Aab }}$ & $27.750^{\text {Bab }}$ & $7.5000^{A D}$ & $13.000^{\mathrm{Aa}}$ & $87.000^{\mathrm{Bab}}$ \\
\hline & $\mathrm{A}+\mathrm{H}$ & $36.900^{\text {Acd }}$ & $25.00^{\mathrm{Bab}}$ & $7.200^{A C}$ & $13.00^{\mathrm{Aa}}$ & $83.100^{\mathrm{Bd}}$ \\
\hline
\end{tabular}

Yo: Yoghurt starter, A: Lb. acidophilus, $\mathrm{H}$ : Lb. helveticus

The different capital letters have a significant effect between treatments at the level 0.05 The different small letters have a significant effect for starter culture at the level 0.05 .

\section{Conclusion}

Regarding the forementioned results, it could be concluded that $\beta$ glucan addition extended the incubation time and decreased TLAB, enhanced the sensory properties of fermented milk, comparing with glucomannan as well as control. Also, by mixing different fermented milk containing probiotic cultures with yoghurt cultures, it could develop the desired texture, flavour, and aroma of final product.

\section{REFERENCES}

Akramiene, D.; Kondrotas, A., Didziapetriene, J. and Kevelaitis, E. (2007). Effects of beta-glucans on the immune system. Medicina (Kaunas) 43(8):597-606.

AOAC. 2012. Official Methods of Analysis of AOAC International, 17th ed. AOAC International, Gaithersburg, MD.

APHA. 2004. American Public Health Association. Standard Methods for the Examination of Dairy Products., 16th Edn. APHA Inc.Washington DC. 
Sobhy, H. M. et al.

Asano,T.;K.Tanaka,S.Suemasu,T.Ishihara, K.Tahara,T.Suzuki, H. Suzuki, S.Fukudo and T. Mizushima (2012).Effects of $\beta-(1,3-1,6)$-D-glucan on irritable bowel syndrome-related colonic hypersensitivity. Biochemical and Biophysical Research Communications,420:444 449.

EL- Dieb, S.M.; Sobhy, H.M.; Emara, E.M.; El- Nawawy, M.A. and El-Aidie, S.A.M. (2014). Preservation of raw cow milk using non thermal treatments. Journal of Food and Dairy Sciences, Vol. 5, No.2.

Benites, V.; Gilharry, R.; Gernat, A.G. and Murillo, J. G. (2008). Effect of dietary mannan oligosaccharide from Bio-Mos or SAF-mannan on live performance of broiler chickens. Journal of Applied Poultry Research, 17: 471-475.

Bozkurt, M.; Küçükyýlmaz, K.; Çatlý, A.U. and Çınar, M. (2009). The effect of single or combined dietary supplementation of prebiotics, organic acid and probiotics on performance and slaughter characteristics of broilers. South African Journal of Animal Science, 39: 197-205.

Chawla, R. and Patil, G.R. (2010). Soluble Dietary Fiber. Comprehensive Reviews in Food Science and Food Safety, (9): 178-196.

Chen, J. and Seviour, R. (2007). Medicinal importance of fungal $\beta-(1 \rightarrow 3)$, $(1 \rightarrow 6)$ - glucans. Micol. Res., 111:635-652.

Corrigan, A.; Horgan, K.; Clipson, N. and Murphy, R.A. (2011). Effect of dietary supplementation with a Saccharomyces cerevisiaemannan oligosaccharide on the bacterial community structure of broiler cecal contents. Applied and Environmental Microbiology, 77: 6653-6662.

Cremonini, F.; Di Caro, S.; Bartolozzi, F.; Armuzzi, A.; Santarelli, L. and Gabrielli, M. (2001). The impact of probiotics in antibioticassociated diarrhea: A meta-analysis of placebo-controlled trials. Gastroenterology, 120(5): A215.

Delatte, S. J.; Evans, J.,Hebra,A.,Adamson, W., Othersen, H. B. and Tagge. E. P. (2001).Effectiveness of $\beta$-glucan collagen for treatment of partial-thickness burns in children. J. Pediatr. Surg., 36(1):113-118.

Driscoll, M.; Hansen, R.; Ding, C.; Cramer, D. E. and Yan, J. (2009). Therapeutic potential of various $\beta$-glucan sources in conjunction with anti-tumor monoclonal antibody in cancer therapy. Cancer Biol. Ther., 8(3):218-225.

EFSA. European Food Safety Agency (2010). Panel on Dietetic Products, Nutrition and Allergies (NDA); Scientific Opinion on the substantiation of health claims related to Yoghurt cultures and improving lactose digestion (ID 1143, 2976) pursuant to Article 13(1) of Regulation (EC)No 1924/2006.EFSA Journal; 8(10):1763. [18pp.]. doi:10.2903/j.efsa.2010.1763. Available online: www.efsa.europa.eu/efsajournal.htm.

EL-Senaity, M. H. (1999).The composition and of cultured buffalo butter milk fermented with mesophilic bacteria. Egyptian Journal of Dairy Science, 27 (2): 269-280. 
Femia, A. P.; Luceri, C.; Dolara, P.; Giannini, A.; Biggeri, A. and Salvadori, M. (2002). Antitumorigenic activity of the prebiotic inulin enriched with oligofructose in combination with the probiotics Lactobacillus rhamnosus and Bifidobacterium lactis on azoxymethane-induced colon carcinogenesis in rats. Carcinogenesis, 23(11): 1953-1960.

Gorbach, S. L. (2000). Probiotics and gastrointestinal health. American Journal of Gastroenterology, 95(1): 52-54.

Hong, F.; Yan, J.; Baran, J.T.; Allendorf, D.J.; ,Hansen, R.D.; Ostroff, G.R.; Xing, P.X.; Cheung, N.K.V. and Ross, G.D. (2004). Mechanism by which orally administered $\beta-1,3$-glucans enhance the tumoricidal activity of antitumor monoclonal antibodies in murine tumor models. J. Immunol., 173: 797-806.

IDF (1990). Milk and Milk Products- Enumeration of Yeasts and Moulds Colony Count at $25^{\circ} \mathrm{C}$. Standard 94B. Brussels : International Dairy Federation.

Kailasapathy, K. and Chin, J. (2000). Survival and therapeutic potential of probiotic organisms with reference to Lactobacillus acidophilus and Bifidobacterium spp. Immunology and Cell Biology, 78(1): 80-88.

Kim, S-J.; Cho, S.Y.; Kim, S.H.; Song, O-J.; Shin, I-S.; Cha, D.S. and Park, H.J. (2008). Effect of microencapsulation on viability and other characteristics in Lactobacillus acidophilus ATCC 43121. LWT 41: 493-500.

Kopp-Hoolihan, L. (2001). Prophylactic and therapeutic uses of probiotics: A review.Journal of the American Dietetic Association,101(2):229-241.

Laugier, O. B.; Spasic', S. D.; Mandic',V. ; Jakovljevic' D.and Vrvic' M.M. (2012).he effects of repetitive alkaline/acid extractions of Saccharomyces cerevisiae cell wall on antioxidative and bifidogenic efficacy.International Journal of Food Science and Technology,47: 369-375.

Luck, H. (1981).Quality control in the dairy industry.In:R.K.Robinson (Ed.).Dairy Microbiology(Vol.II)pp.313-315.Applied Sci.Publishers, Ltd., England.

Maki K.C.; Davidson, M.H.; Witcher M.S.; Dicklin, M.R. and Subbaiah, P.V. (2007). Effects of high-fiber oat and wheat cereals on postprandial glucose and lipid responses in healthy men. International Journal of Vitamin and Nutrition Research, 77 : 347-356.

Miguel, J. C.; Rodriguez-Zas S.L. and Pettigrew J.E. (2004). Efficacy of a mannan oligosaccharide (Bio-Mos) for improving nursery pig performance. Journal of SwineHealth and Production, 12: 296-307.

Moreira, L. R. S. and Filho, E.X.F. (2008). An overview of mannan structure and mannan degrading enzyme systems. Applied Microbiology and Biotechnology, 79: 165-178.

Noh, D. O.; Kim, S. H. and Gilliland, S. E. (1997). Incorporation of cholesterol into the cellular membrane of Lactobacillus acidophilus ATCC 43121. Journal of Dairy Science, 80 (12): 3107-3113.

Rafter, J. (2002). Lactic acid bacteria and cancer: Mechanistic perspective. British Journal of Nutrition, 88: S89-S94. 
Sobhy, H. M. et al.

Reid, G. (1999). The scientific basis for probiotic strains of Lactobacillus. Applied Environmental Microbiology, 65: 3763-3766.

Reid, G.; Charbonneau, D.; Erb, J.; Kochanowski, B.; Beuerman, D. and Poehner, R.. (2003a). Oral use of L. rhamnosus GR-1 and L. fermentum RC-14 significantly alters vaginal flora: Randomized, placebo-controlled trial. Fems Immunology Medical Microbiology, 35: 131-134.

Reid, G.; Saunders, M. E.; Gaskins, H. R.; Gibson, G. R.; Mercenier, A. and Rastall, R. (2003b). New scientific paradigms for probiotics and prebiotics. Journal of Clinical Gastroenterology, 37: 105-118.

Shah, V.B.; Williams, D. L. and Keshvara, L. (2009). Beta-glucan attenuates TLR2- and TLR4- mediated cytokine production by microglia. Neurosci. Lett. 458 111-115.

Tester, R. F. and AL-Ghazzewi, F.H. (2013). Mannans and health, with a special focus on glucomannans. Food Research International, 50: 384-391.

Thammakiti, S.; Suphantharika, M.; Phaesuwan, T. and Verduyn, C. (2004). Preparation of spent brewer's yeast $\beta$ - glucans for potential applications in the food industry. International Journal of Food Science and Technology, 39:21-29.

Tohamy, A.A.; El-Ghor, A.A.; El-Nahas, S.M. and Noshy, M.M. (2003). Betaglucan inhibits the genotoxicity of cyclophosphamide, adriamycin and cisplatin. Mutation Research, 10: 541.

Yoon, T. J.; Kim, T. J.; Lee, H.; Shin, K. S.; Yun, Y. P. and Moon, W.K. (2008).Anti-tumor metastatic activity of $\beta$ - glucan purified from mutated Saccharomyces cerevisiae. Int. Immunopharmacol., 8(1):36-42.

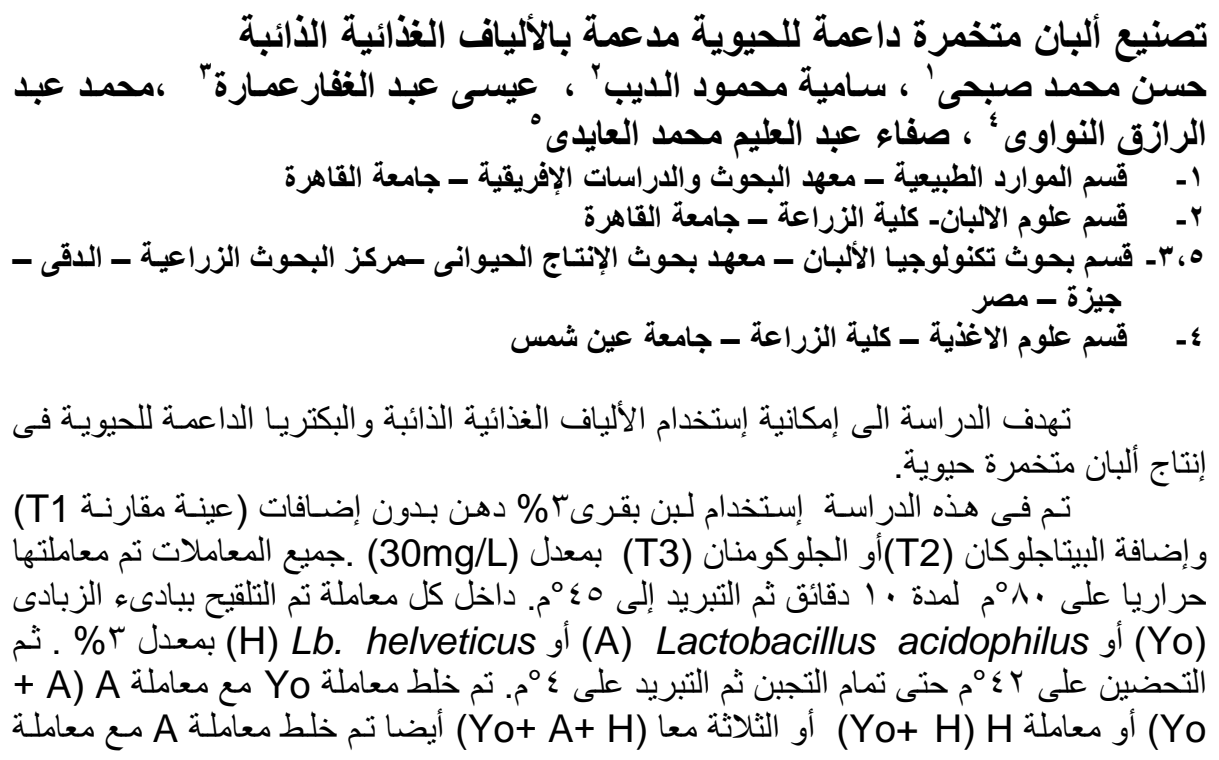




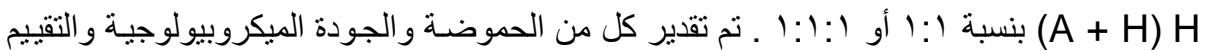

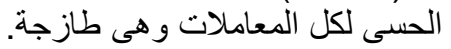
وكاتت أهم النتائج المتحصل علئ عليها ما يلى:-

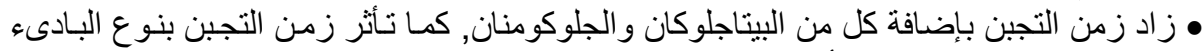

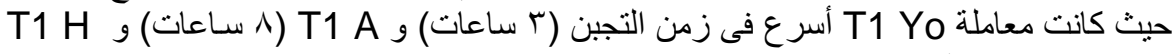

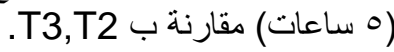
• إحتوت معاملات البيتاجلوكان و الجلوكومنان على أبلى أعداد أقل معنويا من بكتريا حامض اللاكتيك الكلية مقارنة بعينة المقارنة. • إحتوت معاملات اللبن المتخمر بالبادئات الفردية على أعداد أقل معنويا من بكتريا حامض اللاكتيك

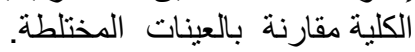
• إحتوت معاملات البيتاجلوكان و الجلوكومنات لعنان على أعداد أقل معنويا من البكتريا المتجرثمة مقارنـة بعينة المقارنة.

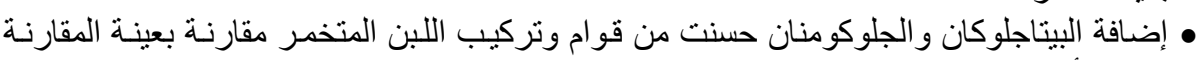

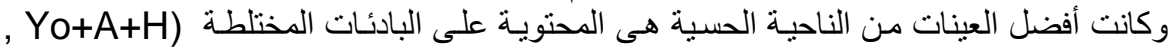

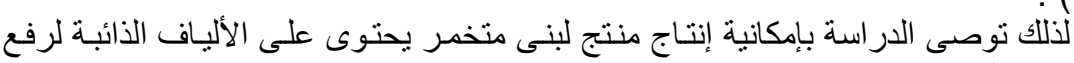
$(\mathrm{Yo}+\mathrm{H}$

كلية الزراعة - جامعة المنصورة كلية الزراعة - جامعة الازهر قيمته التغذوية و الصحية . لرحى

قام بتحكيم البحث أ.د / طام طبم عبد الحليم نصيب أ.د / ماهر احمد نور 